\title{
Reversed epiphanies: roman emperors deserted by gods
}

\author{
Olivier Hekster \\ Radboud Universiteit Nijmegen, Erasmusplein 1, 6525 HT, Nijmegen, The Netherlands \\ o.hekster@let.ru.nl
}

\begin{abstract}
:
According to Suetonius, the emperor Galba was twice visited by the goddess Fortuna in his dreams. At the second occasion, she withdrew her support, preceding Galba's fall. This type of epiphany is rare for Roman emperors, but not unique. The emperor Domitian, too, was visited in his dream by his favourite goddess Minerva, who stated that she was about to abandon him. This article aims to place the passages discussing these dreams in a wider context of Roman ways of dealing with emperors and gods. It will argue that the closer the link between emperor and god was, the more important it became for the god to voluntarily withdraw before an emperor could be dethroned. In doings so, the article draws a parallel to the Roman notion of evocatio in order to understand these 'reversed epiphanies' in which gods appear solely to state that they are leaving.
\end{abstract}

Keywords:

Roman emperors - epiphany - evocatio

\section{Body text:}

Roman emperors, like everybody else, dreamt. ${ }^{1)}$ Emperors, however, were far elevated above their subjects. Thus, dreaming of the emperor tended to bring fortune. ${ }^{2}{ }^{2}$ Likewise, the dreams that emperors had took on a meaning well beyond that of other inhabitants of the Roman Empire. ${ }^{3)}$ Dreams, as other imperial omens, could indicate how power was obtained, used and abused. ${ }^{4)}$ In light of all of this, a rarely analysed series of events in Suetonius's life of Galba is particularly interesting. It starts fairly early in Galba's life:

1 See especially Weber 2000.

2 Artem. Onirocriticus 4.31; Price 1986, 3-37. Cf. for the trust Romans put in the predictive power of dreams Harris 2003.

3 Vigourt 2001; R. Lorsch Wildfang/ J. Isager 2000. Cf. Kragelund 2001 for the political role of dreams in the Republic.

4 For an overview, see Vigourt 2001, 311-341. 
'When he assumed the toga of manhood, he dreamt that Fortuna said that she was tired of standing before his door - and that unless she were quickly admitted, she would fall prey to the first comer. When he awoke, opening the door of the hall, he found close by the threshold a bronze statue of Fortune more than a cubit high. This he carried in his arms to Tusculum, where he usually spent the summer, and consecrated it in a room of his house. And from that time on, he honoured it with monthly sacrifices and a yearly vigil' (Sumpta virili toga, somniavit Fortunam dicentem, stare se ante fores defessam, et nisi ocius reciperetur, cuicumque obvio praedae futuram. Vtque evigilavit, aperto atrio simulacrum aeneum deae cubitali maius iuxta limen invenit, idque gremio suo Tusculum, ubi aestivare consuerat, avexit et in parte aedium consecrato menstruis deinceps supplicationibus et pervigilio anniversario coluit). ${ }^{5)}$

Suetonius' story of the emperor's link to Fortuna continues when he describes the portents relating to Galba's fall. One of the clearest sign, Suetonius states, was when, unaccountably, Galba decided to consecrate to the Capitoline Venus 'a necklace fashioned of pearls and precious stones', which he had in fact set aside 'for the adornment of his Tusculan Fortuna' (Suet. Gal. 18.2). Fortuna's reaction was rapid: 'The next night Fortuna appeared to him in a dream, complaining of being robbed of the gift intended for her and threatening in her turn to take away what she had bestowed'. (proxima nocte somniavit specie Fortunae querentis fraudatam se dono destinato, minantisque erepturam et ipsam quae dedisset) (Suet. Gal. 18.2). Understandably, Galba hastened to Tusculum to make amends, but found on the empty altar only warm ashes (instead of a blazing fire) and furthermore, rather than the customary youth clad in white, carrying incense in an ornate container and holding wine in a luxurious beaker, he saw the opposite: 'an old man dressed in black, holding the incense in a glass dish, and the wine in an earthen cup' (iuxta senem in catino vitreo tus tenentem et in calice fictili merum) (Suet. Gal. 18.2). Galba's Fortuna had gone. His death followed soon.

Interestingly, this seems to be the one direct appearance of Fortuna to an emperor. There were, of course, occasions at which the Fortuna Primigenia from Praeneste gave

\footnotetext{
Suet. Gal. 4.3. Cf. D.C. 64.1.2 who has Fortune likewise appearing to Galba, though in a vision rather than a dream, stating that 'she had now remained by him for a long time, but nobody would grant her admission into his house. If she was left outside for much longer, she would take up her abode with somebody else'. There has been attention to Suetonius' use of portents in his life of Galba, but mainly in order to discuss Suetonius' structuring of his work; Gugel 1977, 60-4; Wallace-Hadrill 1983, 109; Gascou 1984, 447-450; Martinez Gasquez 1988, 19-29; Shotter 1993, 106, 132; Benediktson 19961997, 167-173. Cf. Weber 2000, 187-9.
} 
unfavourable omens, such as in the reigns of Tiberius and Domitian. $\left.{ }^{6}\right)$ But there is a substantial difference between an oracle responding to requests, and the goddess appearing, as it were, in person. Of the latter, Fortuna's appearance to Galba seems unique. This may not be surprising. In general it seems that Fortuna appeared rarely to people in the Roman Empire. Artemidorus, in his Onirocriticus, mentions her twice in passing $(2.34 ; 2.44)$ and only once in a brief discussion (2.37):

Tyche (Chance) standing upon a rolling ball is inauspicious for all men because of the precariousness of the base. But if she is holding a rudder, it foretells movements. For a rudder that does not move is useless. But Chance always indicates good luck when she is seated or reclining. For it signifies safety and stability because of her position. The richer and more attractive she appears, the better she should be considered. Some men maintain that if Chance looks rich and extravagantly adorned, especially if she appears not as a statue but in person, it is a symbol of poverty. For by lavishing a great deal of attention upon herself, she is naturally neglecting mankind. And if Chance is unadorned and does not take care of herself, it foretells wealth and a life of pleasure. For it is apparent that she is taking care not of herself but rather of mankind. But, in my opinion, their reasoning is fallacious. For Chance is nothing other than the very property that dreamers possess.

Notwithstanding the ambiguous meaning of seeing the goddess (at least according to Artemidorus), Galba seems to have paid substantial honour to the goddess. In the short period of his reign, Fortuna appears on both a denarius and aureus type, both minted at Rome. ${ }^{7)}$ This was not the first appearance of Fortuna on the reverse of an imperial coin. During the civil wars, a coin showing Fortuna, with the legend FLORENTE FORTUNA PR was minted in Gaul, by (probably) Vindex, whereas Gaius`sister Julia had appeared with the attributes (if not in the guise) of Fortuna, in an often discussed coin type. ${ }^{8)}$ Galba, however, for the first time put forward the legend FORTUNA AUG(USTI). This was an explicit direct link between emperor and Fortuna, which became quite common in the later empire, but had, until

6 See e.g. Suet. Tib. 63.2; Cal. 57.7; Dom 15.2. On the temple of Fortuna Primigenia see Champeaux 1982-1987, I. 1-147; Plu. Quaest. Rom. 106. Cf. Vigourt 2001, 206-211.

7 RIC I², Galba, p. 238, no. 127, p. 239 no. 128. On earlier associations of Roman generals with Fortuna, see Champeaux 1982-1987, II, 259-261.

8 RIC I' $\mathrm{I}^{2}$, The civil wars, p. 207, no. 49; Gaius, p. 110 , no.33, p. 111 no. 41. On Gaius' coin type, Ginsburg 2006, 65-69; Wood 1988. 
Galba, not appeared at all on imperial coinage. ${ }^{9}$ Perhaps, then, there may have been a perceived link between Galba and the goddess that needed to be severed in order to be able to understand Galba's fall from grace. In many ways, Galba could lay strong claims to the throne. He emphasised both traditional and divine ancestry, being the last of the patrician Sulpicii, who traced back their lineage back to Jupiter himself, and advertising a strong connection to the Julio-Claudian household - by placing Livia's portrait on his coinage, and styling himself 'Lucius Livius Galba'. ${ }^{10}$ ) Perhaps, to understand how such traditionally powerful claims to honour and status were so easily overturned, Fortuna herself needed to abandon him.

In this light, a second example of what could be called 'reversed epiphanies' - gods only appearing to say that they are leaving - may be illustrative. It is the well-known sequence of events foreshadowing Domitian's death. Suetonius writes that Domitian: 'dreamed that Minerva, to whom he had paid superstitious worship, came forth from her sacrarium and said that she could no longer defend him because she had been disarmed by Jupiter (Minervam, quam superstitiose colebat, somniavit excedere sacrario negantemque ultra se tueri eum posse, quod exarmata esset a Iove) (Suet. Dom. 15.3). A somewhat comparable story is recounted by Dio, who mentions a dream of the emperor, in which: 'Minerva, whose statue he kept in his bedroom, had thrown away her weapons and, mounted upon a chariot drawn by black horses, was plunging into the abyss' ( jAqhnah, hif ej $\mathrm{t}$ w/koit whi idr umeshn eiłe, ta; opla ajobeblhkenai kai; eji; ałmato" ippwn melamwn ej' casma espipt ein eøloxen $)^{11)}$

In general, seeing Minerva in a dream was deemed not at all bad for rulers. Artemidorus (2.34) noted that seeing any of the Olympians is beneficial for influential men and women, much like seeing celestials is good for the moderately rich, terrestials good for the poor, chtonics good for farmers and those in hiding, and seeing sea and river gods is a

\footnotetext{
9 For Fortuna Augusti coins issued by later emperors, see for example RIC IV.1, Septimius Severus, no. 376A and RIC V.1, Gallienus sole reign, no. 636. Note, also, that there is some evidence for a golden statue of Fortuna in the imperial bedroom, at least in the second century: HA, Ant. Pius, 12.5; Marc. 7.3; Sev. 27.5, with Erkell 1952, 119.

10 BMCRE I, nos. 201-2, Pl. 58.4; SEG 15.873; Suet. Gal. 2-3; D.C. 64.1; Tac. Hist. 1.49; Plu. Galba 3.12. See further: Hekster 2006, 28. Cf. also Wallace-Hadrill 1981, 37-8.

11 D.C. 67.16 .1 ; Scott 1936, 181.
} 
positive sign for sailors. ${ }^{12)}$ Clearly, however, Domitian's dream was not a good omen. As Artemidorus points out (2.33): 'If the gods depart of their own free will and their statues fall down, it portends death for the dreamer or for one of his family'. The stories surrounding Domitian, in any case, left little room for doubt. Whether Minerva explicitly said that she could no longer protect him, or rode into an abyss, it was rather emphatically not a good sign.

Why Minerva? Again, as with Galba and Fortuna, this is the one example of Minerva appearing directly before an emperor. Indeed, before the reign of Domitian there are no omens relating to Minerva connected to emperors at all. Also, as with Galba and Fortuna, there was a clear link between goddess and emperor, though the case of Domitian and Minerva is much more striking. The association between emperor and goddess is much discussed. Philostratus, when describing Domitian's death in his Life of Apollonius, notes how in his final struggle the emperor kept 'calling upon Minerva to assist him' (8.25), whereas in an earlier encounter the 'emperor had just been offering a sacrifice to Minerva' when Apollonius approached Domitian. In that very encounter Philostratus has Apollonius boldly state: 'I imagined, oh king, that Minerva cared for you as she once did for Diomedes at Troy', before saying that apparently she did not, otherwise 'you might better see Minerva herself and not confuse men with demons' (VA 7.32). The most outrageous anecdote that Philostratus recounts in this respect is that a man 'said that he was being prosecuted because he had failed to include at public sacrifice in Tarentum that Domitian was the son of Minerva' (VA 7.24). Clearly, this evidence is all anecdotal. But it would not have worked if the association between Minerva and Domitian was not well known and broadcast.

Many other authors, in fact, support at least the notion that Domitian considered Minerva his special protectress. Poets capitalised upon the relationship, if only for flattery. Statius has Janus mention the importance 'of your Minerva' (tuae Minervae) shortly after describing Domitian as magne parens mundi. ${ }^{132} \mathrm{He}$ does not forget to mention the fact that the great equestrian statue of Domitian in the Forum placed an image of Minerva in his left

\footnotetext{
12 Specific to Minerva is further that she is a good omen for handicraftsmen, men who are getting married, farmers, philosophers, and those setting out to war. There are, however, contexts in which dreaming of Minerva should be interpreted negatively. Thus, for instance, having sex with a goddess normally meant death for the ill. Yet, if the sex was good it meant assistance from superiors though if 'they did not derive pleasure from the act, it means fear and confusion' (1.80) Minerva, in any case, is one of the goddesses (Artemis, Hecate, Hera, Hestia and Rhea being the others) who are so austere that dreaming of having sex with them always means death in the near future.

13 Stat, Silv. 4.1.22; 4.1.17, with Coleman 1988, ad loc.
} 
hand. ${ }^{14)}$ Martial, as often, is even more obvious, speaking of Pallas Caesariana. ${ }^{15)}$ He also calls Domitian's new Forum the Palladium forum. There was, in fact, a temple built to the goddess - which was dedicated by Nerva. ${ }^{16)}$ Martial further urges the princeps to 'accept the rough breastplate of the warrior Minerva' (Accipe belligerae crudum thoraca Mineruae) (7.1.1) and many poems later returns to this theme: 'Tell me, fierce maid, since you have a helmet and a spear/ why have you no aegis? "Caesar has it"' (Dic mihi, virgo ferox, cum sit tibi cassis et hasta/ Quare non habeas aegida. 'Caesar habet.') (14.179). Minerva, as Martial aptly put it, was seen as 'the confident of our Thunderer' (nostri conscia Tonantis) (6.10.9). So clear was the connection that Minerva could be singled out as Domitian's special consort: 'Of Minerva I say nothing; your interests are hers' (Pallada praetereo: res agit illa tuas). ${ }^{17)}$

One might even be able to say why. Quintilian mentions the emperor's literary aspirations as a reason for Domitian's connection between himself and the goddess:

'what can be more sublime, more learned, and in short more excellent in every detail than these very works of his to which he as a young man devoted himself in seclusion after he had made a gift of the empire (to his father and brother)? Who could better sing of war than he who wages them in such a way? To whom would the goddesses who preside over letters more readily listen? To whom would his tutelary divinity Minerva more willingly reveal her arts?' (Quid tamen his ipsis eius operibus in quae donato imperio iuvenis secesserat sublimius, doctius, omnibus denique numeris praestantius? Quis enim caneret bella melius quam qui sic gerit? Quem praesidentes studiis deae propius audirent? cui magis suas artis aperiret familiare numen Minerva?). ${ }^{18)}$

Domitian's literary attempts and are well attested through the court poets. ${ }^{19)}$ Likewise, the evidence for an explicit link between Minerva and literature in Domitian's reign is clear. The Quinquatria were held in 'the Alban hills of Pallas', and Martial even describes a certain Sextus, evidently a librarian, as 'Palatinae cultor facunde Minervae'. This may well mean that the libraries on the Palatine were entrusted to Minerva's care. ${ }^{20)}$ Cassius Dio further

\footnotetext{
14 Stat. Silv. 1.1.37-9. Cf. Tuck 2005, 231-232.

15 Mart. 8.1.4; Sullivan 1991, 33 refers to Martial as a 'Flavian apologist and propagandist'.

16 Mart. 1.2, 8. On the archaeological evidence for the Forum Transitorium see especially D'Ambra 1993; La Rocca 1998; Bauer, Morselli 1995.

17 Mart. 9.3.10. Cf. Henriksén 1998-9, ad loc.; Garthwaite 1993.

18 Quint. Inst. 10.1, 91; Scott 1936, 171.

19 E.g. Stat. Ach. 1, 14-18; Sil. 3. 618-21; V.Fl. intr., 12-14.

20 Mart. 5.1.1; 5.5.1; Scott 1936, 167, 171; Coleman 1986, 3096.
} 
confirms the importance of Minerva for Domitian, possibly even stressing the connection between the goddess and literature: 'The deity whom he revered most was Minerva, in consequence of which he was wont to celebrate the Pan Athenaea on a magnificent scale; on these occasions he held contests of poets and orators and gladiators almost every year at his Alban villa' (qewh men gar thn jAqhnah ej' ta;makis t a hgalle, kai;dia;t out o kai;ta; P anaqhraia megalw" extst aze, kai; ej auj oi" ag wha" kai; poiht wh kai;logograf wn monoma wn te kat jefo" wJ eipeih ej $\mathrm{t}$ w/ jAlbanw/ ejoiei) (D.C. 67.1.2). Suetonius likewise mentions the 'Quinquatria in honour of Minerva' at which were also held 'contests of orators and poets'. ${ }^{21)}$ Unsurprisingly, all of this was reflected in coinage too. In the words of Mattingly (1926), 'Seldom has one divinity received such numismatic honours from a votary'. ${ }^{22)}$ With such clear and obvious connections between emperor and goddess, it does not seem too speculative to assume that both the emperor himself and the public at large believed the connection to be important. The goddess, then, needed to be overcome before the emperor could be.

There are further stories circulating of gods deserting the emperors, though not through direct epiphany. Tellingly, these too are cases of emperors who emphasised particularly strong connection to the deity in question. Thus, before the death of Commodus, 'footprints of the gods were seen in the Forum departing from it' (Vestigia deorum in foro visa sunt exeuntia), whereas 'in the porticus Minuciae a bronze statue of Hercules sweated for several days' (Herculis signum aeneum sudavit in Minucia per plures dies). ${ }^{23)}$ Hercules, of course, was very much Commodus' deity and hence, allowing for the above sketched reconstruction of events, the one that needed to be overcome in one way or another before the tyrant could be dethroned. ${ }^{24)}$ Nero, whose closeness to Apollo was well documented, may also have lost the god's support in the end - though the evidence is much more roundabout. ${ }^{25)}$ The main constituent is a story from, again, Suetonius' Life of Galba:

Years before, as Livia was returning to her estate near Veii, immediately after her marriage with Augustus, an eagle which flew by dropped into her lap a white hen, holding in its beak a sprig

\footnotetext{
21 Suet. Dom. 4. 4.

22 RIC 2, 151; Carradice 1983, 142; Southern 1997, 60.

23 HA, Comm. 16.2, 16.5.

24 On Commodus and Hercules see Hekster 2001, Hekster 2002, 103-109, 117-128; Meyer-Zwiffelhoffer 2006.

25 On Nero and Apollo see Champlin 2003, 112-144.
} 
of laurel, just as the eagle had carried it off. Livia resolved to rear the fowl and plant the sprig, whereupon such a great brood of chickens was hatched that to this day the villa is called Ad Gallinas, and such a grove of laurel sprang up, that the Caesars gathered their laurels from it when they were going to celebrate triumphs. Moreover it was the habit of those who triumphed to plant other branches at once in that same place, and it was observed that just before the death of each of them the tree which he had planted withered. Now in Nero's last year the whole grove died from the root up, as well as all the hens. Furthermore, when shortly afterwards the temple of the Caesars was struck by lightning, the heads fell from all the statues at the same time, and his scepter, too, was dashed from the hand of Augustus. ${ }^{26)}$

This much seems an obvious story of divine support being withdrawn. The fact that the socalled 'temple of the Caesars' is probably apocryphal makes the trustworthiness of the tale doubtful, but for the purposes of public perception that need not be a problem. For it is noticeable how the laurel - Apollo's leaf - is drawn into the story, as are chickens, which connected to the god as well. ${ }^{27)}$ As Champlin (2003) pointed out recently in his splendid Nero: 'The favor of Apollo, granted to Augustus Caesar was in the end withdrawn from radiant Nero'. ${ }^{28)}$ Again, an emperor had to lose the support of the god with whom he had close and publicly advertised links.

Quite possibly, the system is not quite so neat. But for its validity, it does not really matter whether or not the anecdotal evidence upon which much of it is built, is actually true or not. Omens - and the interpretations of imperial omens especially - are part of a power game. Events are less important than the perception of events. That the emperors were assumed to have seen gods withdrawing support, or that omens were supposed to indicate they were doing so, was sufficient as an explanatory basis for the emperor's loss of power and life.

Of course, this general notion of the withdrawal of divine support, either through 'reversed epiphanies' or through omens, had many precedents. The most famous, arguably, is

\footnotetext{
26 Suet. Gal. 1: Liviae olim post Augusti statim nuptias Veientanum suum revisenti praetervolans aquila gallinam albam ramulum lauri rostro tenentem, ita ut rapuerat, demisit in gremium; cumque nutriri alitem, pangi ramulum placuisset, tanta pullorum suboles provenit, ut hodieque ea villa "ad Gallinas" vocetur, tale vero lauretum, ut triumphaturi Caesares inde laureas decerperent; fuitque mos triumphantibus, alias confestim eodem loco pangere; et observatum est sub cuiusque obitum arborem ab ipso institutam elanguisse. Ergo novissimo Neronis anno et silva omnis exaruit radicitus, et quidquid ibi gallinarum erat interiit. Ac subinde tacta de caelo Caesarum aede capita omnibus simul statuis deciderunt, Augusti etiam sceptrum e manibus excussum est. Cf. Plin. NH 15.136-138 on the grove.

27 Maspero 1997, 162.

28 Champlin 2003, 144.
} 
Iliad 22.212-213: 'As he held the scales by the middle, the doom of Hector fell down deep into the house of Hades - and then, Phoebus Apollo left him' (elke de; mess a labur: ripe d jEkt oro" ai§imon hmar, wet o d jeij' Aidao, lipen deveJF oibo" jApoll wn). There were Roman parallels as well. Sulla's death was said to have been pre-empted by a dream in which his Genius called him. ${ }^{29)}$ The best known example, however, must be Dionysos' leaving of Marc Antony at Alexandria. As Plutarch recounts:

During this night, it is said, about the middle of it, while the city was quiet and depressed through fear and expectations of what was coming, suddenly certain harmonious sounds of all sorts of instruments were heard, and the shouting of a crowd, accompanied by the cries of Bacchic revelry and satiric leaping, as if a troop of revellers... were going forth from the city ... Those who sought the meaning of the sign were of the opinion that the god to whom Antony had always most likened and attached himself was now deserting him. ${ }^{30)}$

What becomes obvious from Plutarch's story is that here the god is leaving the person by leaving the city. That makes one possible framework of interpreting these divine desertions rather obvious. In the Seven against Thebes (217-8) Aeschylos puts forward how: 'people say that a defeated city is abandoned by its gods'. A similar view is expressed in Aeneid 2.351-2, Horace's Ode 2.1.25-8, and perhaps most famously in Tacitus' Historia 5.13.1, when, just before the fall of Jerusalem:

All of a sudden the doors of the shrine opened, and a superhuman voice cried: "The gods are departing": at the same moment the mighty stir of their going was heard

29 App. BC 1.105; Weber 2000, 429-432.

30 En t auth/t h/nukt i; leget ai, mes oush" scedon, ej h\$uciæ/kai;kat hf eiæ/t h" polvew" dia;f obon kai; pros dokiæn t ou' mell ont o" ou§h", aif niđion oj gamwn te pant odapwh ejmel ei" t ina" f wna", akous qhhai kai; bohn oçlou meta; eug̉s mmh kai; phdhsewn saturikwh, wł per qiasou tino", ouk ajor ubw" ejel aumont o": ... ejokei de; t oi" ajalogizomenoi" to; shmeion ajol eipein oJ qeo"' j Ant wrion, w/ makist a s unexomoiwh kai; s unoikeiwh eftut on diet eves en (Plu. Ant. 75.3-4). Cf. the wonderful poem by Kafavis. 'The god abandons Antony': 'When suddenly at the midnight hour an invisible Bacchic revel is heard passing, with exquisite music, with voices - do not lament, pointlessly, your luck that finally gives out, your work that has failed, all you had planned in your life that proved to be false. Like one for long prepared, like a courageous man, say good-bye to her, to the Alexandria who is leaving. Above all, do not deceive yourself, do not say it was a dream, that your hearing was mistaken; do not stoop to such vain hopes as these. Like one for long prepared, like a courageous man, as it becomes you who were considered worthy of such a city, go steadily to the window, and listen with emotion, but without the prayers of complaints of a coward, listen as a final delight to that sound, to the exquisite instruments of the secret Baccich band, and say good-bye to her, the Alexandria you are losing'. 
(Apertae repente delubri fores et audita maior humana vox excedere deos; simul ingens motus excedentium)

The Romans, of course, had institutionalised the system of what is commonly called evocatio. ${ }^{31}$ Tutelary gods needed to be evoked from a city for it to fall. The best known example must be Juno Regina, who in 396 BC was 'persuaded' to leave Veii in order to get her own cult on the Aventine. ${ }^{32)}$ There has been much discussion as to whether the tradition continued in later times - and thus, whether the evocatio of (again) Juno from Carthage as indicated by Servius (A. 12.841) was antiquarian or real. Yet an inscription found in 1970 at Isaura Vetus records what appears to be an evocatio as late as 75 BC. ${ }^{33)}$ Evocatio, then, continued into the late Republic. References in Servius and Macrobius show that knowledge of evocatio at least lasted well into the late Empire. ${ }^{34)}$ The ritual, in any case, was a complicated one, which depended more than anything else on the willingness of the god or goddess to move. ${ }^{35)}$ Thus, when Tarquinius attempted to create the Capitoline temple, and found that the Tarpeian hill was "littered with houses of the gods, it was decided to summon the gods forth (evocare) to new temples; Terminus alone did not want to move (discedere noluit) and so remained". ${ }^{36)}$ In reaction, Terminus, alongside Iuventas and Mars, were included in the temple of the Capitoline Triad. ${ }^{37)}$

This example is not only illustrative for the necessity of the gods' approval for an evocatio, it also shows that evocatio is not always limited to convincing gods to leave a city, nor that the gods in question need to be enemy gods. A fragment from Ulpian, in the early third century, makes matters even more problematic:

31 See most recently Ando 2008, 120-148; Kloppenborg 2005, 434-441; Gustafsson 2000. Cf. Blomart 1997, 99-111, who argues that one should speak of 'gods which are evoked' rather than of a 'process of evocation'. In the 21 literary cases in which gods are evoked, the verb evocare is used 18 times, whereas the actual concept of evocatio is mentioned only three times.

32 Liv. 5.21-22; Gustafsson 2000, 46-55.

33 AE 1977, 816; Hall 1973; Gustafsson 2000, 60-62. Cf. the cautious note by Ando 2008, 132. Kloppenborg 2005, 442-444 even argues that the destruction of the Temple in Jerusalem by Titus ought to be seen as an example of evocatio.

34 Macr. 3.9.6; Serv. A. 2.351; 12.841.

35 Ando 2008, 108 with references

36 Ando 2008, 114 n. 72; Ov. Fast. 2.667-70; Serv. A. 9. 446. Cf. Fest. s.v. nequitum; Liv. 1.55.4; D.H. 3.69.3-6.

37 Tagliamonte 1999. 
It should also be observed that a sacred place is one thing, a sacrarium another. A sacred place is a place that has been consecrated, but a sacrarium is a place in which sacra have been deposited. This could even be in a private building, and it is customary for those who wish to free such a place from its religious scruple to call forth (evocare) the sacra' (Illud notandum est aliud esse sacrum locum, aliud sacrarium. Sacer locus est locus consecratus, sacrarium est locus, in quo sacra reponuntur, quod etiam in aedificio privato esse potest, et solent, qui liberare eum locum religione volunt, sacra inde evocare). ${ }^{38)}$

Interestingly, Ulpian chose not to phrase this as a question of public law, presumably because 'gods have wills of their own, which are subject of external and internal impulses other than priestly or magisterial action. ${ }^{39)}$ Plutarch reflected on the same theme, when he wondered 'Why it is forbidden to mention or to enquire after or to call by name that deity, whether it be male or female, whose especial duty it is to preserve an watch over Rome'. ${ }^{40)}$ As Ogilvie famously noted, "gods, like dogs, will only answer to their names". ${ }^{41)}$ Having the right name gave power over a god, and made it possible to persuade that deity to move elsewhere, if the god was willing.

Yet within these divergent notions of what evocare entailed of, and what the role of the gods themselves was in the process, the literary sources are remarkably consistent on one point. Evocatio includes the physical moving of the deity, almost inevitably through the means of the cult statue. Similarly, Galba's Fortuna was personalised through the statue which came to his door and then left. Domitian's Minerva was present in the cult statue in his bedroom. Is it not possible, then, to see the 'reversed epiphanies' at some level in the wider context of a framework like evocatio? One needed to convince a divinity who supported an emperor to leave that emperor before being able to dethrone him. Dionysos leaving Alexandria, Fortuna leaving Galba and Minerva leaving Domitian, all form part of a similar sort of semi-evocatio. Only after such desertion could power change hands. Ironically, then, a Roman ruler needed to come face-to face with his favourite deity to be told that divine support was over, and his life at an end. Seeing the gods may not always have been a pleasant experience.

\footnotetext{
38 Ulp. dig. 1.8.9.2.

39 Ando 2003, 247.

40 Plu. Quaest. Rom. $61=$ Mor. 278 F.

41 Ogilvie 1969, 24.
} 


\section{Bibliography}

Ando, C. 2003. 'Introduction to Part VI: Space and time', in: idem (ed.), Roman Religion (Edinburgh), 247-251

Ando, C. 2008. The Matter of the Gods. Religion and the Roman Empire (Berkeley/ Los Angeles/ London)

Blomart, A. 1997. 'Die evocatio und der Transfer >fremder< Götter von der Peripherie nach Rom', in: Cancick, H., Rüpke, J. (eds.) Römische Reichsreligion und Provinzialreligion (Tübingen) 99-111

Bauer, H., Morselli, C. 1995. 'Forum Nervae', LTUR 2, 307-311

Benediktson, D. T. 1996/1997. 'Structure and Fate in Suetonius' life of Galba', The Classical Journal, 92. $2,167-173$

Carradice, I. 1983. Coinage and Finances in the Reign of Domitian (Oxford)

Champeaux, J. 1982-1987. Fortuna. Le culte de la fortune à Rome et dans le monde romain des origines à la mort de César 2 Vols. (Rome)

Champlin, E. 2003. Nero (Cambridge [Mass] / London)

Coleman, K.M. 1988. Statius, Silvae, IV (Oxford)

Coleman, K.M. (1986), 'The Emperor Domitian and Literature', ANRW II.32.5, 3087-3115.

D'Ambra, E. 1993. Private Lives, Imperial Virtues. The Frieze of the Forum Transitorium in Rome (Princeton)

Erkell, H. 1952. Augustus, Felicitas, Fortuna. Lateinische Wortstudien (Göteborg)

Garthwaite, J. 1993. 'The Panegyrics of Domitian in Martial Book 9', Ramus 22, 78-102.

Gascou, J. 1984. Suetone, historien (Rome)

Ginsburg, J. 2006. Representing Agrippina: Constructions of Female Power in the Early Roman Empire (Oxford)

Gugel, H. 1977. Studien zur biographischen Technik Suetons (Vienna)

Gustafsson, G. 2000. Evocatio Deorum. Historical and Mythical Interpretations of Ritualised Conquests in the Expansion of Ancient Rome (Uppsala)

Hall, A. 1973. 'A new light on the capture of Isaura Vetus by P. Servilius Vatia', Vestigia 17, $568-571$

Harris, W.V. 2003, 'Roman opinions about the truthfulness of dreams', JRS 93, 18-24

Hekster, O. 2001. 'Commodus-Hercules. The people's princeps', SCI 20, 51-83

Hekster, O. 2002. Commodus. An Emperor at the Crossroads (Amsterdam)

Hekster, O. 2006. 'Descendants of gods: legendary genealogies in the Roman Empire', in De Blois, L., Funke, P., Hahn, J. (eds.) The Impact of Imperial Rome on Religions, Ritual and Religious Life in the Roman Empire (Leiden/ Boston), 24-35

Henriksén, C. 1998/9, Martial, Book IX: A Commentary. 2 Vols. (Uppsala)

Kloppenborg, J. S. 2005. 'Evocatio deorum and the date of Mark', Journal of Biblical Literature 
$124.3,419-450$

Kragelund, P. 2001. 'Dreams, religion and politics in Republican Rome', Historia 50, 53-95

La Rocca, E. 1998. 'Das Forum Transitorium. Neues zu bauplanung und Realisierung', Antike Welt $29,1-12$

Lorsch Wildfang, R., Isager, J. (eds.) 2000. Divination \& Portents in the Roman World (Odense)

Martinez Gasquez, J. 1988. 'Valoración de los praesagios de muerte en las vidas de los doce Cesares', Myrtia. Revista de Filología Clásica 3, 19-29

Maspero, F. 1997. Bestiario Antico. Gli animali-simbolo e il loro significato nell'immaginario dei popoli antichi (Casale Monferrato)

Meyer-Zwiffelhoffer, E. 2006. 'Ein Visionär auf dem Thron? Kaiser Commodus, Hercules Romanus', Klio 88, 189-215

Price, S. 1986. 'The future of dreams: From Freud to Artemidorus', Past and Present 113, 3-37

Scott, K. 1936. The Imperial Cult Under the Flavians (Stuttgart/ Berlin)

Shotter, D. 1993. Suetonius: Lives of Galba, Otho \& Vitellius (Warminster)

Southern, P. 1997. Domitian. Tragic Tyrant (London/ New York)

Sullivan, J. P. 1991. Martial: The unexpected classic. A literary and historical study (Cambridge)

Tagliamonte, G. 1999. 'Terminus, fanum, sacellum, ara', LTUR 5, 27-28

Tuck, S.L. 2005. 'Roman imperial hunting imagery: Domitian and the redefinition of virtus under the Principate', Greece and Rome 52, 221-245

Ogilvie, R. M. 1969. The Romans and their Gods (London)

Vigourt, A. 2001. Les Présages impériaux d'Auguste à Domitien (Paris)

Wallace-Hadrill, A. 1981. 'Galba's Aequitas', Numismatic Chronicle 141, 20-39

Wallace- Hadrill, A. 1983. Suetonius: The Scholar and his Caesars (London)

Weber, G. 2000. Kaiser, Träume und Visionen in Prinzipat und Spätantike (Stuttgart)

Wood, S. 1988. 'Memoriae Agrippinae: Agrippina the Elder in Julio-Claudian art and propaganda', AJA 92, 409-426 